\title{
Exploring the Role of Anxiety and Motivation in Foreign Language Achievement: A Structural Equation Modeling Approach
}

\author{
EBRAHIM KHODADADY \\ Gholam Hassan Khajavy \\ Ferdowsi University of Mashhad (Iran)
}

Received: 11 May 2012 / Accepted: 30 September 2012

ISSN: $1697-7467$

\begin{abstract}
The present study had two purposes. First, the relationship between language anxiety and motivation was examined among Iranian EFL learners. Secondly, a foreign language achievement model based on language learning anxiety and motivation was developed and tested by structural equation modeling. To achieve the purposes, foreign language classroom anxiety scale (FLCAS) and language learning orientations scale (LLOS) were administered to 264 participants. The results of the study showed that amotivation and less self-determined types of external motivation are positively related to language anxiety. Also, intrinsic motivation and identified regulation were negatively related to language anxiety. The application of the structural equation modeling showed that both anxiety and motivation significantly predict the English achievement of the language learners within an Iranian context. Pedagogical implications of the results are discussed.
\end{abstract}

Keywords: Motivation, foreign language, anxiety, achievement.

Explorando el papel de la ansiedad y la motivación en el éxito en adquirir una lengua extranjera: un enfoque extructural del modelado de ecuación

RESUMEN: El presente estudio tuvo dos objetivos. En primer lugar, se examinó la relación que se produce entre la ansiedad y la motivación de estudiantes iraníes de inglés como lengua extranjera. En segundo lugar, se desarrolló un modelo de éxito de aprendizaje de lenguas extranjeras basado en la ansiedad que provoca el aprendizaje de idiomas y la motivación, y se comprobó mediante modelos de ecuaciones estructurales. Para lograr los objetivos se pasaron a 264 participantes una escala de ansiedad en el aula de lengua extranjera (FLCAS) y una la escala de orientación de aprendizaje de idiomas (LLOS). Los resultados del estudio mostraron que la desmotivación y los tipos de motivación externa menos auto-determinados se relacionan positivamente con la ansiedad que produce el aprendizaje de un idioma. Además, la motivación intrínseca y la regulación identificada se relacionan negativamente con la ansiedad de aprender una lengua. La aplicación del modelos de ecuaciones estructurales mostró que la ansiedad y la motivación predicen significativamente el logro en inglés de los estudiantes de lenguas en un contexto iraní. Se discuten también algunas implicaciones pedagógicas de los resultados.

Palabras clave: La motivación, la lengua extranjera, la ansiedad, el logro. 


\section{INTRODUCTION}

Individual differences have been studied extensively by experts in foreign language (FL) learning, i.e., language anxiety and language motivation. Both of these constructs have been found to be highly correlated to FL achievement. However, relatively few studies have examined the role of these two constructs simultaneously in the context of English as a foreign language (EFL). Exploring the relationship between language motivation and language anxiety and their combined effects on the EFL achievement will help language teachers and researchers to clarify the role of these two variables in language pedagogy. The purpose of the present study is to accomplish such a task and examine the relationship between language anxiety and language motivation, and their effects on language achievement within a foreign context.

\subsection{Foreign Language Anxiety}

It is widely believed that learning a foreign language can be a stressful activity for some learners (Hewitt \& Stefenson, 2011). Many researchers have, therefore, examined the role of anxiety in language learning since early 1970s (e.g. MacIntyre \& Gardner, 1991; Phillips, 1992; Aida, 1994; Gardner, 2005). Their findings have shown that there is a negative relationship between FL anxiety and the level of achievement.

Foreign language anxiety has been described by employing different categorizations (Dorneyi, 2005). Two of the most well-known classifications are trait-state (Speilberger, 1983) and facilitating-debilitating (Scovel, 1978) views of anxiety. The former states that trait anxiety is stable over time, while state anxiety is a transient and moment-to-moment feeling. The latter proposes that anxiety does not necessarily impede learning, and in some cases it could improve language performance and have a positive effect on language leaning. In other words, while debilitating anxiety has negative impact on learners' performance, facilitating anxiety can actually enhance it.

MacIntyre (1999) defined foreign language anxiety as "worry and negative emotional reaction aroused when learning or using a second language" (p.27). Horwitz, Horwitz, and Cope (1986) identified three types of foreign language anxiety: communication apprehension, fear of negative evaluation, and test anxiety. They also developed a 33-item questionnaire, Foreign Language Classroom Anxiety Scale (FLCAS) to measure language anxiety. Following this, many studies have been conducted on language anxiety. Although few studies have shown a positive relationship between language anxiety and language achievement (e.g., Liu, 2006; Oxford, 1999), most of them have shown that language anxiety is negatively related to language achievement (e.g., MacIntyre, 1999; Horwitz, 2001; MacIntyre, Noels, Clement, 1997). In other words, the more proficiency learners gain in the EFL, the less anxiety they experience in learning it.

Foreign language anxiety is common among foreign language learners (Young, 1991) and it is seen as one of the great obstacles of FL learning and achievement. Therefore, lower achievement with higher anxiety is attributed to negative effects of anxiety on language learning (Tóth, 2007; MacIntyre, 1999, 2002; Horwitz, 2000, 2001). 


\subsection{Language Motivation}

Dörnyei (2005) stated that motivation "provides the primary impetus to initiate FL learning and later the driving force to sustain language and often tedious learning process" (p. 65). Therefore, motivation is also one of the important affective factors that influence language learning. Research on motivation in second language learning started with the work of social psychologists Gardner and Lambert (1972) and Gardner (1985). They stated that language learning is affected by socio-cultural factors. Consequently, Gardner (1985) proposed the socio-educational model of second language acquisition. In this model, two variables, integrativeness and attitudes toward the learning situation are related to the learners' sociocultural environment. Integrativeness consists of integrative orientation, attitudes toward FL community, and interest in foreign languages. Attitudes toward the learning situation refer to the evaluation of the language teacher and the FL course. Since integrativeness and attitudes toward the learning situation contribute to the learners' level of motivation, these three classes of variables have been called integrative motivation (Gardener, 1985).

However, the social-psychological framework has undergone criticism for being employed in foreign language learning contexts where there is little or no contact with people from the target language. To overcome this shortcoming, and by the emergence of cognitive school in educational psychology, researchers draw on the distinction between intrinsic and extrinsic motivation to overcome the criticism in language leaning (e.g., Noels, Pelletier, Clement, \& Vallerand, 2000). It is based on self-determination theory proposed by Deci and Ryan (1985) and widely used in educational psychology. Intrinsic motivation refers to internal desire to perform an action because it is enjoyable and satisfying. When learning is perceived as goal in itself and students find the task interesting and challenging, they become intrinsically motivated (Ehrman, Leaver, \& Oxford, 2003). Extrinsic motivation, however, comes from external factors driving learning for instrumental goals such as earning reward or avoiding punishment.

Noels et al. (2000) applied self-determination theory to FL research. They identified three types of intrinsic motivation. The first type is knowledge, motivation to do an activity for exploring new ideas and knowledge. The second deals with accomplishment, sensations for achieving a goal or a task. The third type of intrinsic motivation involves stimulation, fun and excitement stimulated by doing a task.

Similarly, Noels et al. (2000) identified three types of extrinsic motivation that vary in their level of self-determination. The least self-determined type of extrinsic motivation is external regulation, which refers to the activities that are external to the learner, such as tangible benefits and costs. The second type of extrinsic motivation which is more internal is introjected regulation. It refers to performing an activity due to some kind of internal pressure such as avoiding guilt or ego-enhancement. The most self regulated type of extrinsic motivation is identified regulation. Students carry out an action due to personally related reasons and attaining a valued goal.

Ramage (1990) showed that intrinsic motivation contributes more strongly to second language achievement than extrinsic motivation. Without focusing on the degree of contribution to learning, Noels et al. (2000), however, stated that when students have no reason, intrinsic or extrinsic, to do an action they will leave the activity as soon as they find a more motivating goal to pursue. 


\subsection{FL Language Anxiety and FL Motivation}

The relationship between language motivation and language anxiety has been investigated by some researchers. In their studies, they have treated anxiety either as a separate factor in its own right or as a secondary factor of FL self-confidence. When considered as a distinct variable, FL anxiety was found to be negatively related to FL motivation (e.g., Gardner \& Lalonde, 1987; Hashimoto, 2002). As a secondary factor of FL self-confidence, anxiety was, however, related to self confidence gained as a result of perceived communicative competence (e.g., Clement, 1980, 1986) Lack of anxiety is thus viewed as a predictor of FL self-confidence characterizing motivated language learners.

Also, the relationship between FL anxiety and self-determination theory of language learning motivation has been examined by some researchers such as Toth (2007) and Liu and Huang (2011). These scholars have shown that anxiety is positively and significantly related to amotivation. They have, however, found that anxiety is more significantly correlated with extrinsic motivation than with intrinsic motivation.

\subsection{English Language Instruction in Iran}

Formal instruction of EFL in Iranian educational system starts from the first year of junior high school (Papi \& Abdollahzade, in press). Dominant method of EFL teaching in Iran is Audiolingualism and Grammar Translation Method in which the emphasis is on learning new lists of vocabulary, explicit teaching of grammar, and reading and translating the texts followed by doing some drills and exercises. Since speaking and listening skills are largely ignored in state high schools for a number of reasons such as class times and facilities, a large number of students go to private language institutes to develop and improve their speaking and listening skills.

Although some studies have examined the FLFL motivation and FLFL anxiety experienced by university or school students in Iranian EFL context, there is still a lack of research on FL motivation and FL anxiety of language learners in the informal and communicative-based context of Iranian private language institutes. The primary purpose of the present study is, therefore, to investigate the relationship of FL motivation and FL anxiety in informal context of private language institutes in Iran. Also, a foreign language achievement model based on the FL anxiety and FL motivation will be examined in this context.

\subsection{Research questions}

1. What is the relationship between motivation and foreign language anxiety in Iranian EFL context?

2. Which types of motivation predict the students' foreign language anxiety in Iranian EFL context?

3. Does the proposed model of foreign language achievement based on FL anxiety and FL motivation show enough adequacy for Iranian EFL context? 


\section{2. МетноD}

\subsection{Participants}

A total of 264 (111 male and 153 female) EFL learners from an Iranian private English language institute in Kashmar city took part in this study. Ages ranged from 16 to 44 (mean= 23.18, $\mathrm{SD}=4.51$ ). All the participants were at the proficiency level of lower intermediate and intermediate. Further descriptive statistics of the participants is presented in Table 1.

Table 1. Participants' descriptive statistics.

\begin{tabular}{llcc}
\hline Category & Sub-category & Number & Percent \\
\hline Nationality & Iranian & 264 & 100 \\
& & & \\
Educational status & High school student & 40 & 15.15 \\
& University student & 124 & 47 \\
& Graduate student & 100 & 37.85 \\
Proficiency level & Lower-intermediate & 142 & 53.78 \\
& Intermediate & 122 & 46.22 \\
Marital status & Single & 197 & 74.6 \\
& Married & 67 & 25.4 \\
\hline
\end{tabular}

\subsection{Materials}

The books used for teaching the EFL in the institute where data were collected are Interchange series written by Richards, Hull and Proctor (2005). The exams are based on the tests designed by the authors in the Teacher's edition of the same books. They measure the reading, writing, speaking, and listening abilities of learners according to the units taught during the school semesters. Each of these tests has a maximum score of 25 . The learners' performance is thus reported on a scale ranging from zero to 100 at the end of each semester. After getting the official approval of the authorities of the institute, the final scores of the participants in the four skills were obtained from the registrar's office as objective measures of learners' EFL achievement.

\subsection{Instruments}

Two questionnaires were used in this study, i.e., Foreign Language Classroom Anxiety Scale and Language Learning Orientations Scale (LLOS). These questionnaires have been well validated and widely used in language learning literature. They were translated into the Persian language by the researchers on the basis of schema theory (e.g., Khodadady, 2001, 2008; Seif \& Khodadady, 2003). Based on this theory, all the words constituting the items were translated by employing their semantic, syntactic, and discoursal relationships with each 
other and their best Persian equivalents were chosen by employing the same relationships governing the Persian equivalents. For example, while the noun phrase "second language" appears in the English version of the LLOS, it was replaced by the single noun Persian equivalent INGILISI (English) because in the context/discourse of the present research is refers only to this specific foreign language.

\subsubsection{Foreign Language Classroom Anxiety Scale}

The Persian version of the Foreign Language Classroom Anxiety Scale developed by Horwitz et al. (1986) was employed in this study. It is the most well-known scale used for measuring anxiety and stress in foreign language classrooms. Participants answered 33 items presented on a Likert-type scale having seven points and ranging from it does not apply to me at all to it applies to me completely. The alpha reliability coefficient reported for the English FLCAS is .93 .

\subsubsection{FL Language Learning Orientations Scale (LLOS)}

The Persian version of Language Learning Orientations Scale (LLOS) was utilized to assess motivation of participants in this study. It was developed by Noels et al., (2003) to measure amotivation, intrinsic motivation, and extrinsic motivation. It consists of twenty one items whose seven points range from it does not apply to me at all to it applies to me completely. Noels et al. administered the LLOS to 159 native speakers of English learning Frensh as a second language an obtained the alpha reliability coefficients of $.82, .75, .67$, $.84, .85, .88$ and .85 for amotivation, external regulation, introjected regulation, identified regulation, intrinsic motivation- knowledge, intrinsic motivation- accomplishment and intrinsic motivation- stimulation, respectively.

\subsection{Procedure}

The researchers talked to eight English teachers offering lower and upper intermediate courses in the specified institute and asked for their cooperation in giving the questionnaires to their students during the regular class time. All of them agreed to cooperate and permitted the researchers to use their class time for distributing the questionnaires. Participants completed them in fifteen minutes in July, 2011. Researchers were present in the classrooms when the participants filled out the questionnaires. Since both scales were in their mother language no questions were raised by the participants.

\section{RESULTS}

\subsection{Exploratory factor analysis}

Exploratory factor analysis was run to examine the underlying structure of FLCAS and LLOS. Principal axis factoring with promax rotation was performed independently for the two scales. Since the KMO statistics obtained for the FLCAS and LLOS were .94 and 
.76, respectively, they showed that the sample selected in the study and the factor analysis employed would probably provide the best common factors. The significant Bartlett's Tests of Sphericity for FLCAS $\left(\mathrm{X}^{2}=3780.151, \mathrm{df}=526, p<.0001\right)$ and LLOS $\left(\mathrm{X}^{2}=2127.339\right.$, $\mathrm{df}=526, p<.0001)$ indicated that their correlation matrices were not identity matrices.

Upon ensuring the suitability of factor analysis, the number of latent variables to be extracted was determined by adopting eigenvalues greater than one, factor loadings greater than .40 , and the scree plot test as criteria. Cross-loading and low loading factors were removed. The analysis resulted in the extraction of four factors for the FLCAS accounting for $51.49 \%$ of the variance. (Factor loadings are presented in Appendix A.)

Eight items loaded on factor1 (Anx1). These items were related to communication anxiety in English class. It was, therefore, named "English communication fear". There were seven items loading on factor2 (Anx2). This factor reflected students' fear of being negatively evaluated in English class. Thus, it was named "fear of negative evaluation". Three items loaded on factor3 (Anx3). This factor indicated students' attitude toward English class and was named "negative attitude toward English". Finally, five items loaded on factor5 (Anx4) These items were related to students' comfortableness and tension in English class. Therefore, this factor was named "comfortableness with English class".

Upon specifying the latent variables underlying the FLCAS, the same extraction method was applied to the LLOS. A six-factor solution was found for FL motivation accounting for $57.16 \%$ of the variance for the scale. (Factor loadings are presented in Appendix B). The extracted factors, i.e., MO1, MO2, MO3, MO4, MO5, and MO6, corresponded to Noel et al.'s (2000) knowledge, amotivation, introjected regulation, accomplishment, identified regulation, and external regulation, respectively. Items related to stimulation, however, either cross-loaded on other factors or had factor loadings lower than .40 and thus were removed from the structure.

Table 2 presents the descriptive statistics as well as Cronbach Alpha internal consistency reliability coefficients of the ten factors extracted from the FLCAS and LLOS. As can be seen, among the factors amotivation and communication fear are the most and least reliable, i.e., $\alpha=.84$ and .68 , respectively. Since the former consists of only three items whereas the latter comprises eight, the low reliability of communication fear might be attributed to the heterogeneity of its constituting items.

Table 2. Composites of variables with Cronbach Alpha coefficients, means, and standard deviations.

\begin{tabular}{ccccl}
\hline Std. Deviation & Mean & Cronbach's $\alpha$ & No. of items & \\
\hline 4.13 & 8.75 & .81 & 7 & $\begin{array}{l}\text { Negative } \\
\text { attitude }\end{array}$ \\
9.49 & 27.99 & .68 & 8 & $\begin{array}{l}\text { Com. fear } \\
8.42\end{array}$ \\
18.48 & .79 & 3 & $\begin{array}{l}\text { Negative } \\
\text { evaluation }\end{array}$
\end{tabular}




\begin{tabular}{lcccl}
5.59 & 15.32 & .76 & 5 & \\
3.20 & 5.20 & .84 & 3 & Amotivation \\
3.20 & 9.78 & .69 & 2 & External \\
4.53 & 10.08 & .68 & 3 & Introjected \\
2.19 & 11.98 & .76 & 2 & Identified \\
3.91 & 16.09 & .73 & 3 & IM Accomplish \\
3.81 & 16.09 & .74 & 3 & IM Knowledge \\
\hline
\end{tabular}

\subsection{Correlations}

Pearson correlations for all variables are presented in Table 3. As can be seen, amotivation was positively and significantly related to all four FLCAS subscales, indicating that the EFL learners who are amotivated feel more anxious in the class than motivated students. Among the three extrinsic motivation subscales, only External regulation was positively and significantly related to all FLCAS subscales except the Comfortableness. Introjected regulation was also positively and significantly related to all FLCAS subscales except Comfortableness. However, Identified regulation, which is the most self regulated type of extrinsic motivation, was negatively and significantly related to two of the FLCAS subscales, namely Comfortableness and Fear of negative evaluation.

Table 3. Correlation matrix.

\begin{tabular}{llllllllll}
\hline \multicolumn{1}{l}{} & 1 & 2 & 3 & 4 & 5 & 6 & 7 & 8 & 9 \\
\hline 1.Amotivation & 1 & & & & & & & & \\
2.External & .01 & 1 & & & & & & & \\
3.Introjected & .10 & $.31^{* *}$ & 1 & & & & & & \\
4.Identified & $-.23^{* *}$ & $.22^{* *}$ & $.21^{* *}$ & 1 & & & & & \\
5.IM Accomplish & -.06 & .00 & $.15^{*}$ & $.31^{* *}$ & 1 & & & & \\
6.IM Knowledge & $-.14^{*}$ & .09 & $.18^{* *}$ & $.28^{* *}$ & $.43^{* *}$ & 1 & & & \\
7.Negative attitude & $.33^{* *}$ & $.13^{*}$ & $.15^{* *}$ & -.11 & -.11 & $-.18^{* *}$ & 1 & & \\
8.Com. fear & $.28^{* *}$ & $.15^{*}$ & $.27^{* *}$ & -.05 & -.06 & -.11 & $.70^{* *}$ & 1 & \\
9.Negative evaluation & $.37^{* *}$ & $.14^{*}$ & $.23^{* *}$ & $-.17^{* *}$ & $-.18^{* *}$ & $-.16^{* *}$ & $.69^{* *}$ & $.70^{* *}$ & 1 \\
10.Comfortableness & $.26^{* *}$ & -.06 & .03 & $-.30^{* *}$ & $-.14^{*}$ & $-.23^{* *}$ & $.50^{* *}$ & $.52^{* *}$ & $.50^{* *}$ \\
11.Reading & $-.27^{* *}$ & .05 & $.13^{*}$ & $.25^{* *}$ & $.33^{* *}$ & $.46^{* *}$ & $-.19^{* *}$ & $-.27^{* *}$ & $-.23^{* *}$ \\
12.Writing & $-.19^{* *}$ & -.02 & .11 & $.17^{*}$ & $.41^{* *}$ & $.25^{* *}$ & $-.27^{* *}$ & $-.23^{* *}$ & $-.30^{* *}$ \\
13.Speaking & $-.12^{* *}$ & -.03 & .00 & $.15^{*}$ & $.30^{* *}$ & $.24^{* *}$ & $-.25^{* *}$ & $-.30^{* *}$ & $-.20^{* *}$ \\
14.Listening & $-.23^{* *}$ & .03 & .02 & $.22^{* *}$ & $.29^{* *}$ & $.38^{* *}$ & $-.14^{* *}$ & $-.27^{* *}$ & $-.16^{* *}$ \\
\hline
\end{tabular}

* Significant at .05 level, ** significant at .01 level

Among the two intrinsic motivation subscales, Accomplishment was negatively and significantly related to Fear of negative evaluation and Comfortableness. Knowledge was negatively and significantly related to all FLCAS subscales except Communication fear. The 
results of this study, therefore, show that intrinsic motivation subscales were negatively and significantly related to FLCAS subscales. Extrinsic motivation subscales, except Identified, were also positively and significantly related to FLCAS subscales. The relationship between Identified regulation and FLCAS subscales was negative. They also reveal a strong relation between FL motivation and foreign language classroom anxiety. These findings are in line with previous studies (e.g., Liu \& Huang, 2011; and MacIntyre, Baker, Clement, \& Donovan, 2003).

\subsection{Regression Analyses}

In order to answer the second question, i.e., which types of motivation predict the students' foreign language anxiety in Iranian EFL context, multiple regressions were performed. To fulfill the function, six motivational subscales were regressed onto each of four FLCAS subtypes and the total foreign language anxiety to obtain the results presented in Table 4. As can be seen, FL motivation accounted for $15 \%$ of the variance in negative attitude toward English $\left[\mathrm{F}(6,257)=8.79, \mathrm{p}<.001\right.$, Adj. $\left.\mathrm{R}^{2}=.15\right]$. Amotivation $(\beta=.28, \mathrm{t}=4.77$, $\mathrm{p}<.001)$, Introjected $(\beta=.13, \mathrm{t}=2.21, \mathrm{p}<.05)$, and Knowledge $(\beta=-.15 \mathrm{t}=-2.35, \mathrm{p}<.05)$ were the three significant predictors of the negative attitude toward English, with Amotivation as the most significant predictor.

Table 4. Regression analysis for foreign language classroom anxiety.

\begin{tabular}{|c|c|c|c|c|c|c|c|c|c|c|}
\hline & \multicolumn{2}{|c|}{ Negative attitude } & \multicolumn{2}{|c|}{ Communication fear } & \multicolumn{2}{|c|}{ Negative evaluation } & \multicolumn{2}{|c|}{ Comfortableness } & \multicolumn{2}{|c|}{ Total anxiety } \\
\hline & $\beta$ & $\mathrm{t}$ & $\beta$ & $\mathrm{t}$ & $\beta$ & $\mathrm{t}$ & $\beta$ & $\mathrm{t}$ & $\beta$ & $\mathrm{t}$ \\
\hline 1.Amotivation & .28 & $4.77 * * *$ & .22 & $3.79 * * *$ & .30 & $5.34 * * *$ & .17 & $2.90 * *$ & .28 & $4.97 * * *$ \\
\hline 2.External & .11 & 1.79 & .08 & 1.39 & .09 & 1.61 & -.03 & -.60 & .08 & 1.37 \\
\hline 3. Introjected & .13 & $2.21 *$ & .25 & $4.05 * * *$ & .23 & $3.95 * * *$ & .11 & 1.80 & .23 & $3.87 * * *$ \\
\hline 4.Identified & -.04 & -.65 & -.03 & -.56 & -.10 & -.175 & -.23 & $-3.64 * * *$ & -.11 & -1.78 \\
\hline 5.IM Accomplish & -.04 & -.62 & -.03 & -.46 & -.12 & $-2.07 *$ & -.01 & -.24 & -.06 & -1.00 \\
\hline 6.IM Knowledge & -.15 & $-2.35 *$ & -.11 & -1.68 & -.08 & -1.37 & -.15 & $-2.31^{*}$ & -.14 & -2.26 \\
\hline $\mathrm{F}(6,257)$ & 8.79 & & 8.30 & & 13.59 & & 8.32 & & 12.31 & \\
\hline $\operatorname{Adj} \cdot R^{2}$ & .15 & & .14 & & .22 & & .14 & & .20 & \\
\hline
\end{tabular}

* Significant at .05 level, ** significant at .01 level, *** significant at .001 level

For Communication fear, FL motivation accounted $14 \%$ of the variance $[\mathrm{F}(6,257)=$ 8.30, $\mathrm{p}<.001$, Adj. $\left.\mathrm{R}^{2}=.14\right]$. Amotivation $(\beta=.22, \mathrm{t}=3.79, \mathrm{p}<.001)$ and Introjected $(\beta=.25$, $\mathrm{t}=4.05, \mathrm{p}<.001)$ were the two significant predictors of the Communication fear, with Introjected as the most significant predictor.

Foreign language motivation also accounted for $22 \%$ of the variance in fear of negative evaluation $\left[\mathrm{F}(6,257)=13.59, \mathrm{p}<.001\right.$, Adj. $\left.\mathrm{R}^{2}=.22\right]$. Amotivation $(\beta=.30, \mathrm{t}=5.34, \mathrm{p}<.001)$, Introjected $(\beta=.23, \mathrm{t}=3.95, \mathrm{p}<.001)$, and Accomplishment $(\beta=-.12, \mathrm{t}=-2.07, \mathrm{p}<.05)$ were the three significant predictors of the fear of negative evaluation, with Amotivation as the most significant.

Furthermore, FL motivation accounted for $14 \%$ of the variance in comfortableness with English class $\left[F(6,257)=8.32, p<.001\right.$, Adj. $\left.R^{2}=.14\right]$. Amotivation $(\beta=.17, t=2.90, p<.01)$, Identified $(\beta=-.23, \mathrm{t}=-3.64, \mathrm{p}<.001)$, and Knowledge $(\beta=-.15, \mathrm{t}=-2.31, \mathrm{p}<.05)$ were the 
three significant predictors of the comfortableness with English class, with Identified as the most significant predictor. And finally, FL motivation accounted for $20 \%$ of the variance in total foreign language anxiety $\left[\mathrm{F}(6,257)=12.31, \mathrm{p}<.001, \mathrm{Adj} . \mathrm{R}^{2}=.20\right]$. Amotivation $(\beta=.28$, $\mathrm{t}=4.97, \mathrm{p}<.001)$ and introjected $(\beta=.23, \mathrm{t}=3.87, \mathrm{p}<.001)$ were its two significant predictors with amotivation as the most significant one.

\subsection{Structural Equation Modeling}

Based on the previous research and review of the literature, a model of three latent variables (FLFL anxiety, FL motivation, and FL achievement) was constructed. Foreign language motivation was speculated to be related to FL anxiety. It is based on the assumption that the more self-determined the students are, the less anxiety they feel (Noels et. al, 2000; Papi, 2010). Therefore, a direct path from FL motivation to FL anxiety was hypothesized. It was also expected that FL motivation and anxiety were closely related to FLFL achievement (Noels et. al, 2000). Following this, paths from FL motivation and anxiety to FL achievement were added. The interrelationships among variables are shown in Fig.1.

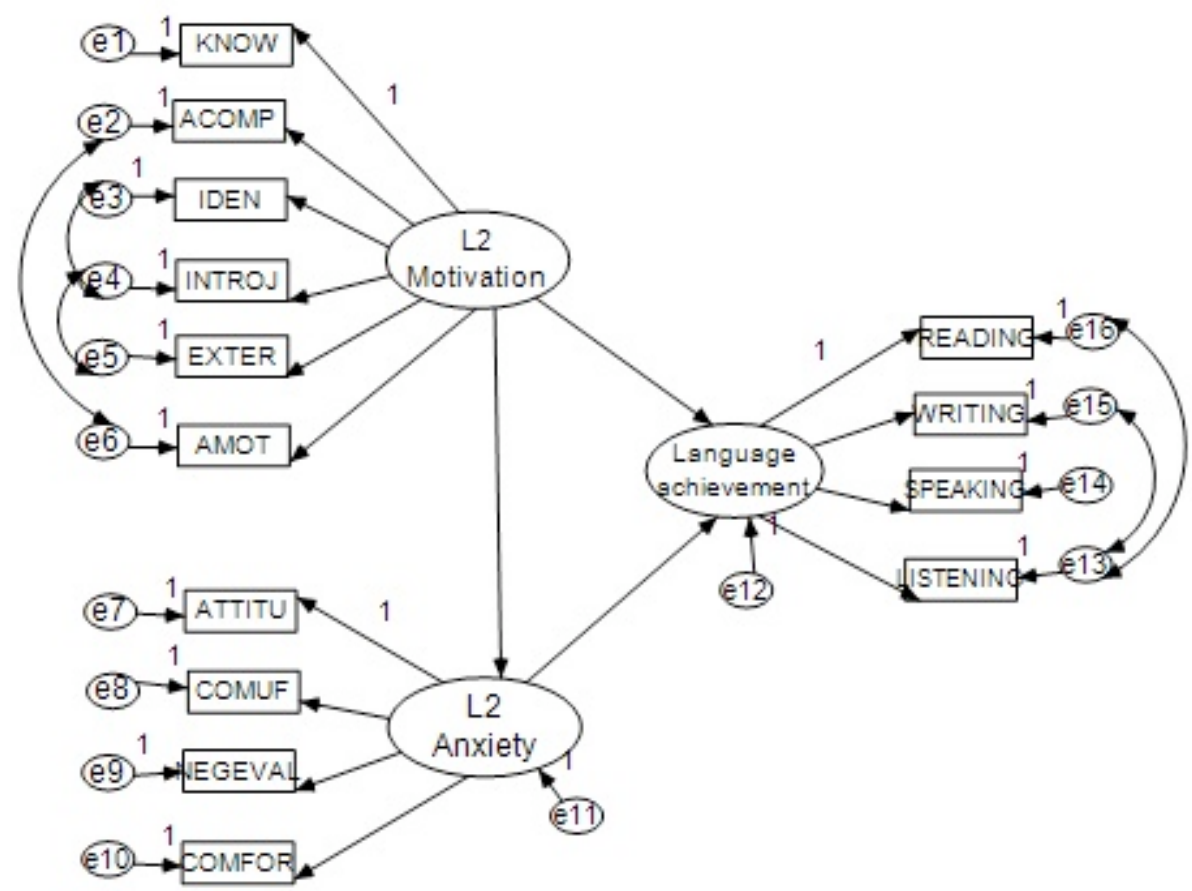

Figure 1. Proposed Structural model of FLFL achievement based on FLanxiety and FL motivation. Indicators: $K N O W=K n o w l e d g e ; A C C O M P=$ Accomplishment; IDEN=Identified; INTROJ=Introjected; EXTER= External; AMOT=Amotivation; ATTITU=Negative

attitude toward English class; COMUF= Communication fear; NEGEVAL= Fear of negative evaluation; $C O M F O R=$ Comfortableness with English class. 
Structural Equation Model (SEM) allows researchers to examine "a series of dependence relationships simultaneously" (Hair, Anderson, Tatham, \& Black, 1998, p. 578). It uses confirmatory hypothesis-testing approach to the analysis of a structural theory. The hypothesized model can be tested to determine the extent to which it is consistent with the data (Hashimoto, 2002).

The proposed model was analyzed using AMOS 16 software. According to some authors such as Peng and Woodrow (2010) and Hair et al. (1998), before testing a structural model, all latent variables should be validated using Confirmatory Factor Analysis (CFA). Following this, some modifications were made (five correlational paths were drawn between the error terms). The CFAs results indicated that the three latent variables fit well as summarized in Table 5.

Table 5. Fit indexes for the measurement models of the three latent variables.

\begin{tabular}{llllllll}
\hline & $\chi^{2}$ & $d f$ & $\chi^{2} / d f$ & GFI & AGFI & CFI & RMSEA \\
\hline FL motivation & 119.88 & 84 & 1.42 & .95 & .91 & .97 & .04 \\
FLCAS & 283.30 & 215 & 1.31 & .91 & .90 & .97 & .03 \\
FL & 2.11 & 1 & 2.11 & .99 & .96 & .99 & .06 \\
achievement & & & & & & & \\
\hline
\end{tabular}

In order to examine the construct validity of the full structural model, chi-square $\left(\chi^{2}\right)$ statistic and some goodness-of-fit measures were used. Because the $\chi^{2}$ statistic is not appropriate for large sample size, $\left(\chi^{2} / d f\right)$ was used, with a value below 3 considered as acceptable (Byrne, 2001). The other fit indices used were goodness of fit index (GFI), adjusted goodness of fit index (AGFI), comparative fit index (CFI), and root mean square error of approximation (RMSEA). For GFI, AGFI, and CFI, it is recommended that a value greater than .90 shows a good fit, and greater than .95 shows a very good fit to the data. For RMSEA, a value lower than .08 is considered acceptable (Byrne, 2001).

Table 6. Fit measures for the final model.

\begin{tabular}{llllllll}
\hline & $\chi^{2}$ & $d f$ & $\chi^{2} / d f$ & GFI & AGFI & CFI & RMSEA \\
\hline Final model & 180.02 & 66 & 2.72 & .92 & .90 & .91 & .06 \\
\hline
\end{tabular}

To check whether the proposed model is appropriate for Iranian EFL context, goodness of fit measures were used. As can be seen in Table 6, goodness of fit measures showed good fit to the data. Therefore, the final model, which is shown in Figure 2, provides an acceptable representation of the FL achievement based on the FL motivation and FL anxiety. Regression coefficients for all paths were significant at least at the .05 level. FL Foreign language motivation and FL anxiety are thus two significant predictors of the FL achievement. 


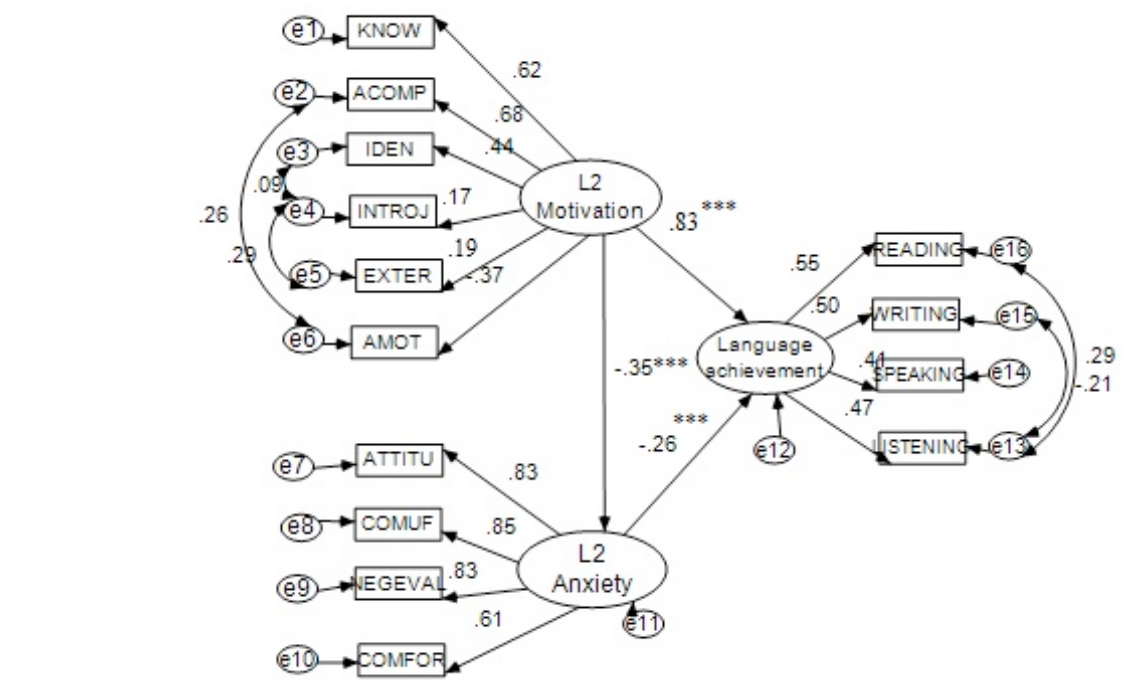

*** Significant at .001 level

Figure 2. SEM results for the final model.

\section{Discussion}

The purpose of this study was to examine the relationship between FL motivation and anxiety and to investigate the simultaneous effect of FL motivation and anxiety on FL achievement. The results indicated that various types of FL motivation are significantly correlated to FL anxiety subscales. In other words, students who have different reasons for learning English are different in their level and type of anxiety. The difference becomes most notable when students who had no motivation are compared to those who were motivated (intrinsic or extrinsic). As can be seen in Table 3, Amotivation was positively and significantly correlated to all four subscales of FL anxiety. Thus, students who lacked motivation to learn English, all had English communication fear, fear of negative evaluation, negative attitude toward English class, and were not comfortable in their classes.

The relations between subscales of FL anxiety and intrinsic/extrinsic motivation were also interesting. Of the three subscales of extrinsic motivation, external and introjected regulations were positively correlated to all $\mathrm{FL}$ anxiety subscales except comfortableness with English class. Therefore, students who learnt English to gain some benefits or to avoid punishment all had English communication fear, fear of negative evaluation, and negative attitude toward English class. However, the most self-determined type of extrinsic motivation, identified regulation, was negatively correlated to two subscales of FL anxiety, negative attitude toward English class and comfortableness with English class. Therefore, among the three extrinsic motivation subscales, students who learn English for personally relevant reasons to achieve a valued goal feel less anxiety comparing with those who learn English for some type of internal or external pressure. 
Furthermore, both intrinsic motivation subscales were negatively and significantly correlated to FL anxiety. FL learners who were intrinsically motivated to achieve a goal did not have a negative attitude toward English class and felt comfortable with it. Also, FL learners who were intrinsically motivated to develop knowledge did not have English communication fear, negative attitude toward English class, and were comfortable with their English class. These results are consistent with the past research in that greater anxiety in the English class was associated with amotivation, and lower levels of identified regulation and intrinsic motivation (e.g., Noels, Clément \& Pelletier, 1999; Tremblay \& Gardner, 1995). Language learners who have no motivation to study English and those who study English for external reasons (except identified regulation) feel more anxious than those students who learn English for intrinsic reasons.

Regression analyses used to check the predictability of the FL anxiety by FL motivation indicated that Amotivation and introjected regulation were the two significant predictors of the total FL anxiety. So, students who have no reason to study English and those who learn English due to some kind of internal pressure, feel the greatest anxiety in the English class. What is notable here is that among the less self-determined types of external motivation, Introjected regulation and External regulation, only Introjected regulation was a predictor of total FL anxiety. It means students who learn English to avoid the guilt or for ego-enhancement (internal pressure) are more anxious than those who learn English to gain some tangible benefits (external source).

Structural equation modeling was also used to explore the simultaneous effect of FL motivation and anxiety on FL achievement. The results of SEM indicated adequate fit to the data, confirming the interrelationships among FL motivation, anxiety, and achievement. Motivation specified as an exogenous variable, had six composite indicator variables. Among these six variables, Accomplishment (regression coefficient $=.68$ ) and Knowledge (regression coefficient=.62) had the highest loadings on FL motivation. It shows that language learners' motivation is highly affected by their sensations for achieving a goal and their desire to explore new ideas and knowledge. As seen in Figure 2, regression coefficient for the path from FL motivation to achievement was .82, indicating that FL motivation is the most significant predictor of achievement. Motivation also had an indirect influence on FL achievement through anxiety (i.e. $-.35 \times-.26=.09$ ). It suggests that motivated students feel less anxiety, and subsequently are more proficient in English. As expected, FL motivation had a negative effect on anxiety (regression coefficient $=-.35$ ). This significant negative path from motivation to anxiety suggests that motivated students feel less anxious in the classroom.

The direct path from anxiety to FL achievement was negatively significant (regression coefficient $=-.26$ ). Therefore, language learners who fear to communicate in English and are afraid of negative evaluation have a negative attitude toward English class, do not feel comfortable with English class and are less proficient in English.

There are a number of implications in the findings of this study that language teachers and researchers should be aware of. First, motivation is negatively and significantly related to anxiety, showing that by increasing students' motivation their anxiety decreases. Therefore, language teachers should motivate their students in order to decrease their anxiety in the English class. However, as the results showed, only intrinsic motivation and identified regulation (the most self-determined type of extrinsic motivation) were negatively related to anxiety. As the second implication of the study, it indicates that motivating the language 
learners by only more self-determined types of motivation can decrease anxiety. Although extrinsic motivation can lead to intrinsic motivation under certain circumstances, teachers should use techniques that foster students' intrinsic motivation. As Dörnyei (1994) pointed out teachers should introduce tasks that stimulate intrinsic motivation and help students to internalize it. For this purpose, interesting, stimulating, and challenging tasks should be used in FL classes.

Anxiety was negatively related to language achievement. It, therefore, offers the third implication that in order to improve students' English achievement, it is necessary for both language teachers and learners to take action to decrease FL anxiety level. Teachers can decrease language learners' anxiety by creating a supportive and relaxing learning environment, providing training in learning strategies, setting goals that are not too easy or too difficult, and using anxiety-reducing techniques (Dörnyei, 1994).

Finally, the present study was conducted in a private language institute. Further research can extend the scope and examine its findings in formal settings such as EFL universities and schools which are usually more anxiety provoking places than institutes. The proficiency level of EFL learners can also be controlled to find out whether certain levels are more anxiety provoking than others. And finally the gender and age of participants were not controlled in this study. So, by taking account of these two important variables, the future study can shed more light on the relationships among motivation, anxiety and achievement in foreign language learning.

\section{REFERENCES}

Byrne, B. M. (2001). Structural Equation Modeling with AMOS: Basic Concepts, Applications, and Programming. New Jersey: Lawrence Erlbaum.

Deci, E., \& Ryan, R. (1985). Intrinsic motivation and self-determination in human behavior. New York: Plenum Press.

Dörnyei, Z. (1994). "Motivation and motivating in the foreign language classroom", in The Modern Language Journal, 78: 273-284.

Dörnyei, Z. (2005). The psychology of language learner: Individual differences in second language acquisition. Mahvah, NJ: Lawrence Erlbaum.

Ehrman, M. E., Leaver, B. L., \& OXford, R. L. (2003). "A brief overview of individual differences in second language learning", in System, 31: 313-330.

Gardner, R. C. (1985). Social psychology and second language learning: The roles of attitudes and motivation. London: Edward Arnold.

Hair, J. F., Anderson, R. E., Tatham, R. L., \& Black, W. C. (1998). Multivariate Data Analysis. New Jersey: Prentice Hall.

Hewitt, E., \& Stephenson, J. (2011). "Foreign language anxiety and oral exam performance: A replication of Phillips's MLJ study", in The Modern Language Journal, 96: 170-189.

Horwitz, E. K. (2000). "It ain't over til it's over: On foreign language anxiety, first language deficits, and the confounding of variables", in The Modern Language Journal, 84: 256-259.

Horwitz, E. K. (2001). "Language anxiety and achievement", in Annual Review of Applied Linguistics, 21: 112-126.

Horwitz, E. K., Horwitz, M. B., \& Cope, J. (1986). "Foreign language classroom anxiety", in The Modern Language Journal, 70: 125-132. 
Khodadady, E. (2001). "Schema: A theory of translation". In S. Cunico (Ed.). Training Translators and Interpreters in the New Millennium, Portsmouth 17th March 2001 Conference Proceedings. Portsmouth, England: University of Portsmouth, School of Languages and Areas Studies, 107-123.

Khodadady, E. (2008). "Measuring translation ability and achievement: A schema-based approach", in Quarterly Journal of Humanities, Al-Zahra University, 18: 56-76.

Liu, M. (2006). "Anxiety in EFL classrooms: causes and consequences" in TESL Reporter, 39: $13-32$.

Liu, M., \& Huang, W. (2011). "An exploration of foreign language anxiety and English learning motivation", in Education Research International, 12: 1-8.

MacIntyre, P. D. (1999). "Language Anxiety: A Review of Literature for Language Teachers". In D. J. Young (Ed.), Affect in foreign language and second language learning. New York: Mc Graw Hill Companies, 24-43

MacIntyre, P. D. (2002). "Motivation, anxiety and emotion in second language acquisition". In P. Robinson (Ed.), Individual differences and instructed language learning. Amsterdam: John Benjamins Publishing Compan, 45-68.

MacIntyre, P. D., Baker, S. C., Clement, R., \& Donovan, L. A. (2003). "Sex and age effects on willingness to communicate, anxiety, perceived competence, and FL motivation among junior high school French immersion students", in Language Learning, 53: 137-165.

MacIntyre, P. D., Noels, K. A., \& Clement, R. (1997). "Biases in self-ratings of second language achievement: The role of language anxiety", in Language Learning, 47: 265-287.

Noels, K., A., Clément, R., \& Pelletier, L. G. (1999). "Perceptions of teacher communicative style and students' intrinsic and extrinsic motivation", in The Modern Language Journal, 83: 23-34.

Noels, K., A., Pelletier, L. G., Clément, R., \& Vallerand, R. J. (2000). "Why are you learning a second language? Motivational orientations and self-determination theory" in Language Learning, 50: 57-85.

Oxford, R. L. (1999). "Anxiety and language learner: new insights". In J. Arnold (Ed.), Affect in Language Learning. Cambridge, UK: Cambridge University Press, 260-278.

Papi, M. (2010). "The L2 motivational self system, L2 anxiety, and motivated behavior: A structural equation modeling approach", in System, 38: 467-479.

Papi, M., \& Abdollahzade, E. (in press). "Teacher motivational practice, student Motivation, and possible L2 Selves: An examination in the Iranian EFL context", in Language Learning.

Peng, J., \& Woodrow, L. (2010). "Willingness to communicate in English: A Model in the Chinese EFL classroom context", in Language Learning, 60: 834-876.

Phillips, E. M. (1992). "The effects of language anxiety on students' oral test performance and attitudes" in The Modern Language Journal, 76: 14-26.

Richards, J. C., Hull, J. , \& Proctor, S. (2005). Interchange level 2 student's book.Third edition. New York: Cambridge University Press.

Richards, J. C., Hull, J. , \& Proctor, S. (2005). Interchange level 3 student's book. Third edition. New York: Cambridge University Press.

Richards, J. C., Hull, J. , \& Proctor, S. (2005). Interchange level 2 teacher's book.Third edition. New York: Cambridge University Press.

Richards, J. C., Hull, J. , \& Proctor, S. (2005). Interchange level 3 teacher's book.Third edition. New York: Cambridge University Press.

Ramage, K. ) 1990). "Motivational factors and persistence in foreign language study", in Language Learning, 40: 189-219. 
Seif, S. \& Khodadady, E., (2003). "Schema-based cloze multiple choice item tests: measures of translation ability", in Universite de Tabriz, Revue de la Faculte des Letters et Sciences Humaines, Langue, 187: 73-99.

Sparks, R. L., Ganschow, L., \& Javorsky, J. (2000). "Déjà Vu All Over Again: A Response to Saito, Horwitz and Garza", in The Modern Language Journal, 84: 251-25.

Spielberger, C. D. (1983). State-Trait Anxiety Inventory (Form Y) manual. Palo Alto: Consulting Psychologist Press.

Tóth, Z. (2007). "Predictors of foreign-language anxiety: Examining the relationship between anxiety and other individual learner variables". In J. Horváth \& M. Nikolov (Eds.), Empirical studies in English applied linguistics. Pécs: Lingua Franca Csopor, 123-148.

Tremblay, P. F., \& Gardner, R. C. (1995). "Expanding the motivation construct in language learning", in The Modern Language Journal, 79: 505-518.

Weiner, B. (1992). Human motivation: Metaphors, theories and research. Newbury Park: CA: Sage.

Young, D. (1991). "Creating a low-anxiety classroom environment: What does language anxiety research suggest?", in The Modern Language Journal, 75: 426-439. 


\section{APPENDIX A}

Factor Loadings of FLCAS items

\begin{tabular}{|c|c|c|c|c|c|}
\hline & Items & Anx 1 & Anx2 & Anx3 & Anx4 \\
\hline 4 & $\begin{array}{l}\text { It frightens me when I don't understand what the teacher is saying in } \\
\text { English. }\end{array}$ & .56 & & & \\
\hline 9 & $\begin{array}{l}\text { I start to panic when I have to speak without preparation in English } \\
\text { class. }\end{array}$ & .55 & & & \\
\hline 10 & I worry about the consequences of failing my English class. & .51 & & & \\
\hline 15 & I get upset when I don't understand what the teacher is correcting. & .51 & & & \\
\hline 29 & $\begin{array}{l}\text { I get nervous when I don't understand every word the language } \\
\text { teacher says. }\end{array}$ & .64 & & & \\
\hline 30 & $\begin{array}{l}\text { I feel overwhelmed by the number of rules you have to learn to } \\
\text { speak a foreign language. }\end{array}$ & .58 & & & \\
\hline 31 & $\begin{array}{l}\text { I am afraid that the other students will laugh at me when I speak the } \\
\text { foreign language. }\end{array}$ & .48 & & & \\
\hline 33 & $\begin{array}{l}\text { I get nervous when the language teacher asks questions which I } \\
\text { haven't prepared in advance. }\end{array}$ & .53 & & & \\
\hline 3 & $\begin{array}{l}\text { I tremble when I know that I'm going to be called on in language } \\
\text { class. }\end{array}$ & & .43 & & \\
\hline 6 & $\begin{array}{l}\text { During language class, I find myself thinking about things that have } \\
\text { nothing to do with the course. }\end{array}$ & & .50 & & \\
\hline 12 & In language class, I can get so nervous I forget things I know. & & .41 & & \\
\hline 17 & I often feel like not going to my language class. & & .57 & & \\
\hline 19 & $\begin{array}{l}\text { I am afraid that my language teacher is ready to correct every } \\
\text { mistake I make. }\end{array}$ & & .51 & & \\
\hline 20 & $\begin{array}{l}\text { I can feel my heart pounding when I'm going to be called on in } \\
\text { language class. }\end{array}$ & & .54 & & \\
\hline 28 & When I'm on my way to language class, I feel very sure and relaxed. & & .50 & & \\
\hline 1 & $\begin{array}{l}\text { I never feel quite sure of myself when I am speaking in my foreign } \\
\text { language class. }\end{array}$ & & & .59 & \\
\hline 26 & $\begin{array}{l}\text { I feel more tense and nervous in my language class than in my other } \\
\text { classes. }\end{array}$ & & & .54 & \\
\hline 27 & $\begin{array}{l}\text { I get nervous and confused when I am speaking in my language } \\
\text { class. }\end{array}$ & & & .57 & \\
\hline 5 & It wouldn't bother me at all to take more foreign language classes. & & & & .40 \\
\hline 8 & I am usually at ease during tests in my language class. & & & & .44 \\
\hline 14 & $\begin{array}{l}\text { I would not be nervous speaking the foreign language with native } \\
\text { speakers. }\end{array}$ & & & & .57 \\
\hline 22 & I don't feel pressure to prepare very well for language class. & & & & .42 \\
\hline 32 & $\begin{array}{l}\text { I would probably feel comfortable around native speakers of the } \\
\text { foreign language. }\end{array}$ & & & & .57 \\
\hline
\end{tabular}




\section{APPENDIX B}

\section{Factor Loadings of LLOS items}

\begin{tabular}{|c|c|c|c|c|c|c|c|}
\hline & Items & MO1 & MO2 & MO3 & MO4 & MO5 & MO6 \\
\hline 16 & $\begin{array}{l}\text { For the pleasure that I experience in knowing more } \\
\text { about the literature of the second language group. }\end{array}$ & .73 & & & & & \\
\hline 17 & $\begin{array}{l}\text { For the satisfied feeling I get in finding out new } \\
\text { things. }\end{array}$ & .55 & & & & & \\
\hline 18 & $\begin{array}{l}\text { Because I enjoy the feeling of acquiring knowledge } \\
\text { about the second language community and their way } \\
\text { of life. }\end{array}$ & .92 & & & & & \\
\hline 1 & $\begin{array}{l}\text { I cannot come to see why I study a second language, } \\
\text { and frankly, I don't give a damn. }\end{array}$ & & .72 & & & & \\
\hline 2 & $\begin{array}{l}\text { Honestly, I don't know; I truly have the impression of } \\
\text { wasting my time in studying a second language. }\end{array}$ & & .91 & & & & \\
\hline 3 & $\begin{array}{l}\text { I don't know; I can't come to understand what I am } \\
\text { doing studying a second language. }\end{array}$ & & .71 & & & & \\
\hline 7 & $\begin{array}{l}\text { Because I would feel ashamed if I couldn't speak to } \\
\text { my friends from the second language community in } \\
\text { their native tongue. }\end{array}$ & & & .65 & & & \\
\hline 8 & $\begin{array}{l}\text { Because I would feel guilty if I didn't know a second } \\
\text { language. }\end{array}$ & & & .70 & & & \\
\hline 9 & $\begin{array}{l}\text { To show myself that I am a good citizen because I can } \\
\text { speak a second language. }\end{array}$ & & & .66 & & & \\
\hline 13 & $\begin{array}{l}\text { For the enjoyment I experience when I grasp a } \\
\text { difficult construct in the second language. }\end{array}$ & & & & .73 & & \\
\hline 14 & $\begin{array}{l}\text { For the satisfaction I feel when I am in the process of } \\
\text { accomplishing difficult exercises in the second } \\
\text { language. }\end{array}$ & & & & .73 & & \\
\hline 15 & $\begin{array}{l}\text { For the pleasure I experience when surpassing myself } \\
\text { in my second language studies. }\end{array}$ & & & & .52 & & \\
\hline 10 & $\begin{array}{l}\text { Because I choose to be the kind of person who can } \\
\text { speak more than one language. }\end{array}$ & & & & & .79 & \\
\hline 12 & $\begin{array}{l}\text { Because I choose to be the kind of person who can } \\
\text { speak a second language. }\end{array}$ & & & & & 67 & \\
\hline 4 & In order to get a more prestigious job later on. & & & & & & .86 \\
\hline 5 & In order to have a better salary later on. & & & & & & .66 \\
\hline
\end{tabular}

Note. Factor loadings lower than .40 were not included. MO1= intrinsic motivation - knowledge; $\mathrm{MO}$ =amotivation; $\mathrm{MO} 3=$ introjected regulation; $\mathrm{MO} 4=$ intrinsic motivation - accomplishment; MO5=identified regulation; MO6= external regulation. 